Institut für Immunologie und Genetik, Deutsches Krebsforschungszentrum, Heidelberg, Federal Republic of Germany

\title{
A Combination of Soluble Helper Factors Bypasses the Requirement for Stimulator Cells and Induces Nonspecific Cytotoxic T Cell Responses
}

\author{
DANIELA N. MÄNNEL, W. DRÖGE, and W. FALK \\ Received November 29, 1984 - Accepted in Revised Form February 12, 1985
}

\begin{abstract}
The specificity of cytotoxic $\mathrm{T}$ lymphocyte (CTL) responses generated in the presence of lymphokines was studied. Thymic responder cells were activated in the presence of stimulator cells that differed in their metabolic activity. After 5 days of culture, the cytotoxic response was estimated in a $4-\mathrm{h}^{51} \mathrm{Cr}$-release test. Coculture of thymic responders with irradiated splenic stimulator cells in the presence of interleukin 2 (IL 2) led to preferential cytolysis of target cells that expressed the same histocompatibility antigens as the cells used for sensitization. Addition of $\mathrm{T}$ cell cytotoxicity-inducing factor 1 (TCF1), however, to those cultures made the presence of stimulator cells unnecessary and induced cytotoxic responses against all target cells tested, including target cells syngeneic to the responder cells. This activation was neither due to contaminating mitogen nor to the effect of heterologous serum in the assay system. The conclusion of these findings was that either polyclonal activation of CTL was induced by TCF1 or that some specific CTL clones differentiated into unrestricted killer cells under the influence of TCF1.
\end{abstract}

\section{Introduction}

Metabolically active antigen-presenting cells are required in order to stimulate both allo- $(1,2)$ and $\mathrm{H}$-2-restricted $(3,4) \mathrm{T}$ cell responses. Production of IL $1(5)$ and subsequently of IL $2(4,6)$ are essential for the antigen-independent proliferation of IL 2 reactive Lyt-2 $2^{+}$CTL precursor cells (7). IL 2 reactivity has been shown to be induced by a short exposure to specific ligands including allo- $\mathrm{H}-2$ antigens (8). The process of this induction requires metabolic activity and active response of resting $T$ cells (8).

A number of recent reports described the involvement of soluble factors other than IL 2 in the induction of CTL responses (9-16). The question

\footnotetext{
Abbreviations: Con $A=$ Concanavalin A; IL $1=$ interleukin 1 ; IL $2=$ interleukin 2; IFN$\gamma=$ interferon-gamma; $T N P=$ trinitrophenyl; $C T L=$ cytotoxic $\mathrm{T}$ lymphocyte $T C F 1=\mathrm{T}$ cell cytotoxicity-inducing factor $1 ; S R=$ spontaneous release
} 
whether these factors are involved in IL 2 responsiveness or at later stages of CTL maturation is unclear.

In this study, we report on the loss of antigen-specificity of the cytotoxic response when thymic responder cells were supplied with all required helper activities. Recently, we described the requirement for at least two helper factors, other than IL 2, for the differentiation of thymic precursor cells into cytotoxic effector cells $(14,17)$. One helper activity was required in the early phase of culture and was named $\mathrm{T}$ cell cytotoxicity-inducing factor 1 (TCF1). This activity was shown to be different from interleukin 1 (IL 1), IFN- $\gamma$, and colony stimulating factor (CSF). The requirement for the late-acting helper activity ( $\mathrm{T}$ cell cytotoxicity inducing factor 2 ) was no longer seen when large amounts of semipurified IL 2 or recombinant IL 2 $(>40 \mathrm{U} / \mathrm{ml})$ were added to the thymocyte cultures. The data presented here show that the presence of stimulator cells was no longer required when preparations containing both IL 2 and TCF1 were added to the cultures and that the resulting cytotoxic response was nonspecific.

\section{Materials and Methods}

\section{Mice}

$\mathrm{C} 3 \mathrm{H} / \mathrm{TIF}$ and DBA/2J were purchased from Bomholtgard, Ry, Denmark. C57BL/6 and $\mathrm{Balb} / \mathrm{c}$ were bred in our own colony. All animals used were between 1 and 3 months of age.

\section{Culture medium}

Unless otherwise stated, the culture medium used was RPMI 1640 (GIBCO, powdered media) with L-Glutamine $\left(2 \times 10^{-3} \mathrm{M}\right)$ and supplemented with $10 \%$ heat-inactivated fetal calf serum (FCS), Hepes $(0.02 \mathrm{M})$, 2-mercaptoethanol $\left(4 \times 10^{-5} \mathrm{M}\right)$ and gentamicin $(50 \mu \mathrm{g} / \mathrm{ml})$. The protein-free culture medium used in some experiments is exactly as described by PECK and BACH (18). This medium was supplemented by $0.6 \%$ heat-inactivated autologous mouse serum.

\section{Lymphokine preparations}

Concanavalin A- (Con A, Pharmacia) induced supernatants were prepared by conventional methods. Spleen cell suspensions were adjusted to $10^{7}$ cells $/ \mathrm{ml}$ in culture medium and incubated for $24 \mathrm{~h}$ with $5 \mu \mathrm{g}$ Con $\mathrm{A} / \mathrm{ml}$ in humidified atmosphere containing $5 \% \mathrm{CO}_{2}$. Lymphokine preparations were stored at $4^{\circ} \mathrm{C}$.

\section{Lymphokine preparations prepared by pulsing with Con $A$}

Spleen cells $\left(10^{7} / \mathrm{ml}\right)$ were incubated in culture medium containing $10 \mu \mathrm{g}$ Con A/ml. After 5 to $6 \mathrm{~h}$ the cells were washed 3 times with culture medium. Cells were readjusted to $10^{7}$ cells/ $\mathrm{ml}$ and cultured in Con A-free culture medium for $24 \mathrm{~h}$ at $37^{\circ} \mathrm{C}$. The maximal amount of Con A remaining in the supernatant was less than $0.01 \mu \mathrm{g} / \mathrm{ml}$ as determined by using tracelabelled Con A.

\section{Absorption of IL 2}

Con A-induced supernatants were depleted of IL 2 by absorption with an IL 2 receptorbearing T cell line. Approximately $10^{5} \mathrm{~W}-2$ cells (14) were added to $1 \mathrm{ml}$ of Con A supernatant 
and incubated for $48 \mathrm{~h}$. The cell-free supernatant was dialysed against culture medium and then incubated again for $48 \mathrm{~h}$ with $10^{5} \mathrm{~W}-2$ cells per ml. The supernatant was again dialysed against culture medium. IL 2 activity was less than $0.01 \mathrm{U} / \mathrm{ml}$.

\section{Preparation of partially purified IL 2}

IL 2 was prepared as described by HILFIKER et al. (19). EL-4 thymoma cells were suspended at $10 \% / \mathrm{ml}$ in RPMI 1640 containing $0.5 \%$ heat-inactivated FCS. Ten nanograms per $\mathrm{ml}$ of phorbol myristic acetate (PMA) were added, and the cells were incubated for $48 \mathrm{~h}$. The cellfree supernatant was concentrated on an Amicon PM10 membrane. Proteins were precipitated with ammonium sulphate ( $80 \%$ saturation). The precipitate was washed once and dissolved in water. After equilibration with $0.8 \mathrm{M}$ ammonium sulphate in $0.01 \mathrm{M}$ phosphate buffer, the sample was applied to a Phenyl-Sepharose column (Pharmacia). The column was washed with 2 volumes of $0.64 \mathrm{M}$ ammonium sulphate containing $10 \%$ ethanediol. The IL 2-containing peak was finally eluted with $40 \%$ ethanediol in $0.16 \mathrm{M}$ ammonium sulphate, concentrated on an Amicon PM10 membrane and equilibrated with column buffer $(0.05 \mathrm{M}$ Tris-hydroxymethylacetate, $0.1 \mathrm{M}$ sodium chloride, $\mathrm{pH} 7.2$, containing $0.05 \%$ polyethylene glycol 6000 ). The material was then applied to a Sephadex G 100 column. IL 2 activity eluted with an apparent molecular weight of approximately 32,000 . Peak fractions were pooled and dialysed against culture medium after adding FCS to a final concentration of $10 \%$.

\section{Assay for IL 2 activity}

The amount of IL 2 in supernatants was measured by their ability to support the growth of the IL 2-dependent cell line W-2 (14). Thymidine incorporation after a 20-h incubation and a 4-h pulse with $1.0 \mu \mathrm{Ci}$ of methyl- $\left({ }^{3} \mathrm{H}\right)$-thymidine $\left({ }^{3}(\mathrm{H})-\mathrm{TdR}\right.$, specific activity $50 \mathrm{Ci} / \mathrm{mmol}$, Amersham International Ltd, Amersham, UK) was determined. Activity is expressed in units used by FARRAR et al. (6).

\section{$T$ cell cytotoxicity assay}

Thymic responder cells or nylon wool-purified spleen cells were cocultured in a final volume of $0.16 \mathrm{ml}$ containing varying amounts of lymphokine preparations. Stimulator cells were $3 \times 10^{5}$ glutaraldehyde-fixed or X-irradiated $(1500 \mathrm{R})$ allogeneic or TNP-haptenated syngeneic spleen cells, unless indicated otherwise. Cytotoxic activity was measured on day 5 in a 4-h ${ }^{51} \mathrm{Cr}$-release test using either $5 \times 10^{3}$ labelled tumor targets (L929 mouse fibrosarcoma) or $2 \times 10^{4}$ (unmodified or TNP-modified) Con A-induced spleen cell blasts. Data are presented as specific ${ }^{51} \mathrm{Cr}$-release (experimental count - spontaneous release/SDS count - spontaneous release) $\times 100$. Spontaneous release $(S R)$ was determined in supernatants of wells without added lymphokines. Data are means of triplicate cultures. The standard error was always less than $2.5 \%$.

\section{Nylon wool treatment}

Splenic responder cells were purified by one passage through a nylon wool column, according to Julius et al. (20).

\section{Results}

\section{Induction of alloantigen-specific CTL responses in the presence of IL 2}

Varying numbers of thymic responder cells were cultured for 5 days with $\mathrm{X}$-irradiated allogeneic splenic stimulator cells in microcultures. The CTL response was measured by offering either syngeneic or allogeneic Con $\mathrm{A}$ blasts targets with the stimulator cells. As shown in Figure 1, no lytic 


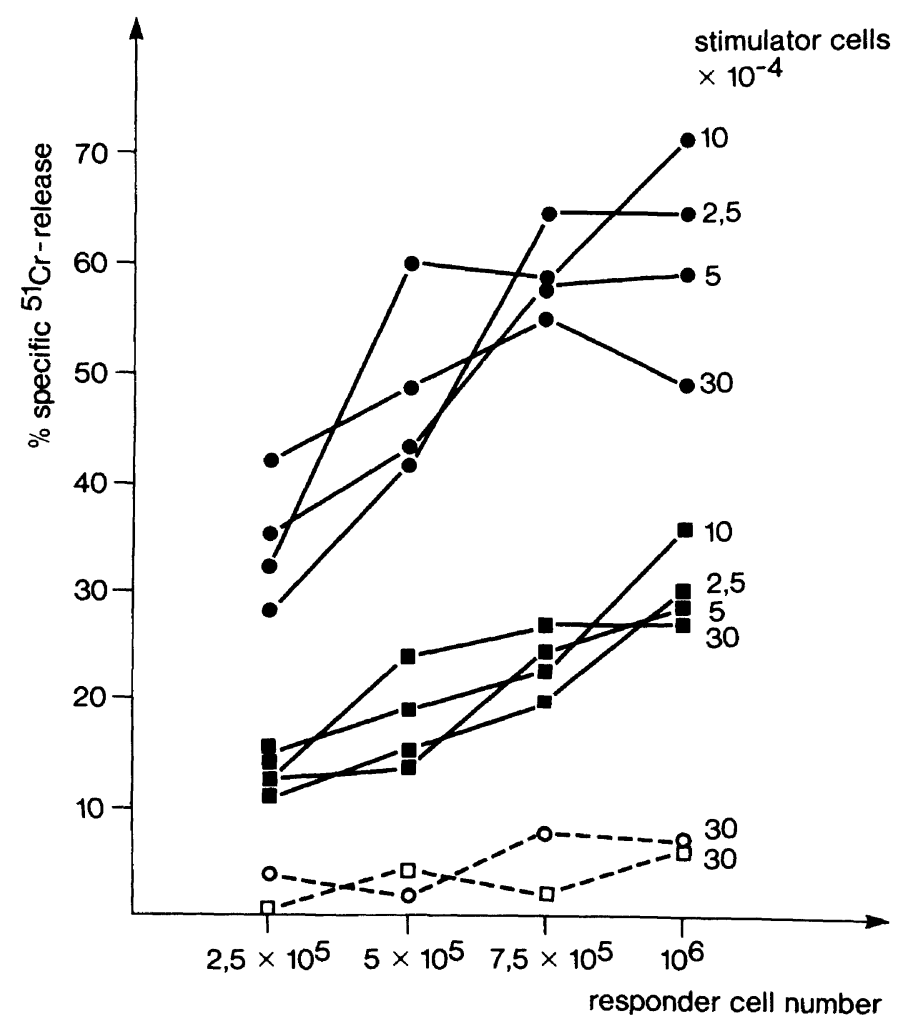

Fig. 1. Varying numbers of $\mathrm{C} 57 \mathrm{BL} / 6$ thymic responder cells were incubated with varying numbers of gamma-irradiated $(1500 \mathrm{R})$ splenic stimulator cells of either $\mathrm{C} 3 \mathrm{H}(\mathbf{O})$ or $\mathrm{Balb} / \mathrm{c}$ (a) mice. $10 \mu \mathrm{l}$ of IL 2 derived from EL-4 supernatant ( $800 \mathrm{U} / \mathrm{ml} \mathrm{IL} \mathrm{2)} \mathrm{was} \mathrm{added} \mathrm{to} \mathrm{the}$ cultures. The data represent $\%$ specific ${ }^{51} \mathrm{Cr}$-release measured on $2 \times 10^{4}$ prelabelled $\mathrm{C} 3 \mathrm{H}$ targets. Without the addition of helper factors, less than $10 \%$ specific ${ }^{51} \mathrm{Cr}$-release was measured at all responder or stimulator doses (open symbols). When Balb/c targets were used, corresponding specificity was obtained.

activity was seen in the absence of added helper factors. However, in the presence of IL 2, cytotoxicity was observed for both targets. In both cases, the response was not dependent upon the number of stimulator cells used in the test. The cytotoxic response measured on targets syngeneic with the stimulators was at all responder numbers significantly higher than the cross-reactivity measured on inappropriate targets. This observation was confirmed in experiments with different strain combinations.

Table 1 shows the degree of specificity and cross-reactivity in the presence of IL 2 in a representative experiment. In all experiments where metabolically active stimulator cells were used, preferential lysis of the sensitizing alloantigen was observed. Taking the respective lysis of stimulator-syngeneic target cells as $100 \%$, the lysis of the $\mathrm{H}$-2-different target cells was $47 \%$ with DBA targets and $61 \%$ with C57BL/6 targets. 
Similar data were obtained with other responder cells. Little cytolytic activity $(<10 \%)$ was induced by IL 2 preparations alone in the absence of stimulator cells.

Table 1. Stimulator-dependent cytotoxic responses in presence of IL 2

\begin{tabular}{|c|c|c|c|c|}
\hline \multirow[t]{3}{*}{ Responder $^{2}$} & \multirow[t]{3}{*}{ Stimulator } & \multirow[t]{3}{*}{ IL $2^{\mathrm{b}}$} & \multicolumn{2}{|c|}{$\%$ specific ${ }^{51} \mathrm{Cr}$-release ${ }^{\mathrm{c}}$} \\
\hline & & & \multicolumn{2}{|c|}{ Target: } \\
\hline & & & DBA & $\mathrm{C} 57 \mathrm{BL} / 6$ \\
\hline $\mathrm{C} 3 \mathrm{H}$ & - & - & 0.0 & 0.1 \\
\hline $\mathrm{C} 3 \mathrm{H}$ & - & + & 0.0 & 9.2 \\
\hline $\mathrm{C} 3 \mathrm{H}$ & C57BL/6 & - & 0.0 & 0.0 \\
\hline $\mathrm{C} 3 \mathrm{H}$ & C57BL/6 & + & 14.3 & 57.6 \\
\hline $\mathrm{C} 3 \mathrm{H}$ & DBA & - & 0.0 & 0.0 \\
\hline $\mathrm{C} 3 \mathrm{H}$ & DBA & + & 30.3 & 35.4 \\
\hline
\end{tabular}

${ }^{a}$ Five $\times 10^{5}$ thymic responder cells were incubated with $3 \times 10^{5}$ of the indicated gammairradiated $(1.500 \mathrm{rad})$ stimulator cells.

${ }^{\mathrm{b}}$ Ten $\mu$ l of semipurified IL $2(800 \mathrm{U} / \mathrm{ml}$ IL 2$)$ was added to some of the cultures.

c After 5 days of culture \% specific ${ }^{51} \mathrm{Cr}$-release was measured in a 4 -h release test with $2 \times 10^{4}$ prelabelled target cells. Experiments with $\mathrm{C} 57 \mathrm{BL} / 6$ responder cells and $\mathrm{C} 3 \mathrm{H}$ or $\mathrm{DBA}$ stimulator cells have also been performed and gave corresponding results.

Table 2. Effect of stimulator quality on cytotoxic responses in the presence of different lymphokines

\begin{tabular}{clrrr}
\hline Stimulator $^{\mathrm{a}}$ & Lymphokines $^{\mathrm{b}}$ & \multicolumn{3}{c}{$\%$ specific $^{51}$ Cr-release } \\
\cline { 3 - 5 } & & \multicolumn{3}{c}{ Target: } \\
\cline { 3 - 5 } & & $\mathrm{C} 3 \mathrm{H}$ & C57BL/6 & Balb/c \\
\hline C3H gamma-irradiated & IL 2 & 0.0 & 0.0 & 0.0 \\
C3H gamma-irradiated & IL 2 + TCF1 & 62.8 & 38.5 & 19.0 \\
C3H gamma-irradiated & Con A lymphokine & 54.3 & 48.4 & 22.4 \\
C3H gamma-irradiated & - & 4.1 & 0.0 & 12.9 \\
C3H glutaraldehyde-fixed & IL 2 & 13.6 & 4.7 & 1.1 \\
C3H glutaraldehyde-fixed & IL 2 + TCF1 & 44.3 & 18.5 & 20.3 \\
C3H glutaraldehyde-fixed & Con A lymphokine & 32.7 & 13.1 & 8.3 \\
C3H glutaraldehyde-fixed & - & 0.0 & 0.0 & 0.0 \\
- & IL 2 & 3.9 & 1.4 & 3.0 \\
- & IL 2 + TCF1 & 45.4 & 25.0 & 24.2 \\
- & Con A lymphokine & 42.2 & 28.4 & 20.2 \\
- & & &
\end{tabular}

a Two $\times 10^{5} \mathrm{Balb} / \mathrm{c}$ thymic responder cells were incubated with $3 \times 10^{5}$ of the indicated stimulator cells for 5 days.

${ }^{\mathrm{b}}$ The following lymphokine preparations were added to the cultures: IL 2, semipurified from EL-4 supernatant ( $800 \mathrm{U} / \mathrm{ml}$ IL 2), $20 \mu$; TCF1, IL 2-absorbed C3H Con A lymphokine (<0.01 U/ml IL 2), $60 \mu \mathrm{l}$; C3H Con A lymphokine (79 U/ml IL 2) $60 \mu \mathrm{l}$.

${ }^{c}$ The data represent $\%$ specific ${ }^{51} \mathrm{Cr}$-release from $2 \times 10^{4}$ prelabelled target cells. The TCF1 preparation alone had no activating effect. 
Table 3. Induction of cytotoxic responses with TCF1 and recombinant IL $2^{2}$

\begin{tabular}{lc}
\hline Lymphokines $^{\mathrm{b}}$ & $\%$ specific ${ }^{51}$ Cr-release $^{\mathrm{c}}$ \\
\hline- & 0.2 \\
Con A lymphokine & 65.0 \\
TCF1 & 0.5 \\
IL 2 & 5.5 \\
Recombinant IL 2 & 3.2 \\
IL 2 + TCF1 & 80.8 \\
Recombinant IL 2 + TCF1 & 69.8
\end{tabular}

${ }^{2}$ One $\times 10^{5} \mathrm{C} 3 \mathrm{H}$ thymic responder cells were incubated with $3 \times 10^{5}$ glutaraldehyde-fixed TNP-modified syngeneic stimulator cells.

${ }^{b}$ The following lymphokine preparations were added to the cultures: $\mathrm{C} 3 \mathrm{H}$ Con A lymphokine (79 U/ml IL 2), $60 \mu \mathrm{l}$; TCF1, IL 2-absorbed C3H Con A-lymphokine $(<0.01 \mathrm{U} / \mathrm{ml}$ IL 2), $60 \mu$ l; IL 2, semipurified from $\mathrm{EL}_{4}$ supernatant ( $800 \mathrm{U} / \mathrm{ml}$ IL 2), $20 \mu \mathrm{l}$; recombinant IL $2(800 \mathrm{U} / \mathrm{ml}$ IL 2$), 20 \mu \mathrm{l}$.

${ }^{c}$ The data represent $\%$ specific ${ }^{51} \mathrm{Cr}$-release from $5 \times 10^{3}$ prelabelled TNP-modified L929 target cells.

\section{Replacement of stimulator cells by TCF1}

The data in Table 2 demonstrate that the requirement for TCF1 in addition to IL 2 was dependent on the quality of the stimulator cells. Thymic responder cells could be induced for cytotoxicity with irradiated splenic stimulator cells, provided the cultures contained IL 2. About the same level of cytotoxicity was measured when either a combination of IL 2 and TCF1, or Con A-induced supernatant was added. The same responder population developed little or no cytotoxic activity with metabolically inactive stimulators or without any stimulator cells, although the same amount of IL 2 was present. The cytotoxic responses developed with TCF1 and IL 2 were not specific for the stimulating antigen. Irrelevant and even syngeneic targets were lysed under these conditions. TCF1 alone had no activating effect in any of the cultures.

Table 3 demonstrates that the semipurified IL 2 used in all the experiments could be replaced by recombinant IL 2 at the same concentration without changing the cytotoxic responses obtained. Cultures containing metabolically inactive stimulator cells and $80 \mathrm{U}$ IL $2 / \mathrm{ml}$ were only dependent on the addition of TCF1 preparations for induction of cytotoxicity. Even very much higher concentrations of IL 2 (up to $1000 \mathrm{U}$ per ml) did not eliminate the requirement for TCF1 (data not shown).

The data in Figure 1, Table 1, and Table 2 suggest that the cytotoxicity induced in cultures of X-irradiated stimulator cells and thymic responder cells may be due to endogenous TCF1. TCF1 itself confers no antigen specificity, as no differences were observed when TCF1 preparations from different mouse strains were tested (Table 4). Nonspecific activation by residual Con $\mathrm{A}$ was excluded since supernatants from Con A-pulsed spleen cells were used as a source of TCF1. In these supernatants, less than $0.01 \mu \mathrm{g}$ 
Table 4. Cytotoxic responses in the presence of IL 2 and TCF1 from Con A-pulsed lymphokines

\begin{tabular}{lcclc}
\hline Responder & Stimulator & IL $2^{\mathrm{b}}$ & TCF1 $^{\mathrm{b}}$ & $\begin{array}{l}\% \text { specific }{ }^{51} \text { Cr-release } \\
\text { Target : C3H }\end{array}$ \\
\hline Balb/c & C3H gamma-irradiated & - & - & 1.9 \\
Balb/c & C3H gamma-irradiated & + & - & 37.9 \\
Balb/c & C3H gamma-irradiated & + & DBA & 59.0 \\
Balb/c & C3H gamma-irradiated & + & C3H & 55.1 \\
Balb/c & - & - & - & 5.4 \\
Balb/c & - & + & - & 7.5 \\
Balb/c & - & + & DBA & 41.2 \\
Balb/c & - & + & C3H & 20.9 \\
C57BL/6 & C3H gamma-irradiated & - & - & 6.4 \\
C57BL/6 & C3H gamma-irradiated & + & - & 59.9 \\
C57BL/6 & C3H gamma-irradiated & + & DBA & 61.6 \\
C57BL/6 & C3H gamma-irradiated & + & C3H & 59.6 \\
C57BL/6 & - & - & - & 8.6 \\
C57BL/6 & - & + & - & 9.4 \\
C57BL/6 & - & + & DBA & 22.7 \\
C57BL/6 & - & + & C3H & 19.9 \\
& & - & &
\end{tabular}

${ }^{2}$ Two $\times 10^{5}$ thymic cells of the indicated strain were incubated with or without $3 \times 10^{5}$ stimulator cells.

${ }^{\mathrm{b}}$ The following lymphokine preparations were added to the cultures: IL 2, semipurified EL-4 supernatant $(800 \mathrm{U} / \mathrm{ml}$ IL 2$) 20 \mu \mathrm{l}$; TCF1, Con A-pulsed lymphokine from either DBA spleen cells $(9.5 \mathrm{U} / \mathrm{ml}$ IL 2 ) or C3H spleen cells ( $26 \mathrm{U} / \mathrm{ml}$ IL 2$), 20 \mu \mathrm{l}$.

${ }^{c}$ The data represent $\%$ specific ${ }^{51} \mathrm{Cr}$-release from $2 \times 10^{4}$ prelabelled $\mathrm{C} 3 \mathrm{H}$ target cells.

Con $\mathrm{A} / \mathrm{ml}$ was detectable using trace labelled Con $\mathrm{A}$. Such concentrations of Con A did not cause polyclonal activation in our assay system (data not shown). Comparable amounts of semipurified IFN- $\gamma$ and IL 1 were unable to substitute for TCF1 $(14,17)$.

Induction of cytotoxic activity against syngeneic targets in the presence of helper factors

$\mathrm{C} 3 \mathrm{H}\left(\mathrm{H}-2^{\mathrm{k}}\right)$ thymocytes or nylon wool-purified spleen cells were stimulated with IL 2 and TCF1 (Table 5) and tested on L929 syngeneic targets. Again, polyclonal activation by remaining Con $\mathrm{A}$ in the TCF1 preparation was excluded by utilizing a mitogen-pulsed spleen cell supernatant with less than $0.01 \mu \mathrm{g}$ Con $\mathrm{A} / \mathrm{ml}$.

Induction of cytotoxic responses in cultures supplemented with autologous serum

The same experiments as described above were carried out in medium containing autologous mouse serum instead of fetal calf serum. The purpose of these experiments was to test whether the FCS in the cultures could be 
Table 5. Cytotoxic activity against syngeneic targets in the presence of IL 2 and TCF1

\begin{tabular}{llll}
\hline Responder & IL $2^{\mathrm{b}}$ & TCF1 $^{\mathrm{b}}$ & $\begin{array}{l}\text { \% specific }{ }^{51} \mathrm{Cr}_{\text {-release }}^{\mathrm{c}} \\
\text { Target: L929 }\end{array}$ \\
\hline A) C3H thymocytes & - & - & 1.2 \\
& + & - & 0.0 \\
& + & + & 0.0 \\
& + & + & 53.8 \\
\hline B) C3H spleen cells & - & - & 1.3 \\
& + & - & 7.3 \\
& - & + & 0.6 \\
& + & + & 35.7 \\
\hline C) C3H spleen cells & - & - & 4.9 \\
& + & - & 10.2 \\
& - & + & 0.0 \\
& + & + & 32.4
\end{tabular}

${ }^{a}$ One $\times 10^{5}$ thymic cells or $1 \times 10^{5}$ 2-times nylon wool-purified splenic cells were used as responder cell population and cultured without stimulator cells.

${ }^{b}$ The following lymphokine preparations were added to the cultures: IL 2, semipurified EL-4 supernatant ( $800 \mathrm{U} / \mathrm{ml}$ IL 2) $20 \mu \mathrm{l}$; TCF1 in A and B, IL 2-absorbed C3H Con A lymphokine $(<0.1 \mathrm{U} / \mathrm{ml}$ IL 2), $40 \mu \mathrm{l}$; TCF1 in C, Con A-pulsed C3H lymphokine (26 U/ml IL 2), $60 \mu \mathrm{l}$.

c The data represent $\%$ specific ${ }^{51} \mathrm{Cr}$-release from $5 \times 10^{3}$ prelabelled L929 target cells.

the reason for the nonspecific cytotoxic responses induced with TCF1 plus IL 2. FCS has been shown not only to provide antigenic determinants recognized by $\mathrm{T}$ cells (21) but also to stimulate helper $\mathrm{T}$ cell activity (22) and polyclonal $\mathrm{T}$ cell responses (23).

Table 6. Cytotoxic responses induced with IL 2 and TCF1 in cultures supplemented with autologous serum

\begin{tabular}{llrrr}
\hline IL 2 & TCF1 & & \multicolumn{2}{c}{$\%$ specific ${ }^{\mathrm{s}}$ Cr-release } \\
\cline { 3 - 5 } & & & \multicolumn{3}{c}{ Target: } \\
& & TNP-L929 & C3H & C57BL/6 \\
\hline- & - & $0.0 \pm 0.5$ & $3.1 \pm 2.3$ & $1.3 \pm 0.9$ \\
+ & - & $0.0 \pm 0.3$ & $0.8 \pm 1.5$ & $1.5 \pm 2.6$ \\
- & + & $0.2 \pm 0.7$ & $3.1 \pm 2.6$ & $2.6 \pm 0.7$ \\
+ & + & $12.8 \pm 2.6$ & $12.4 \pm 3.4$ & $8.1 \pm 0.7$ \\
\hline
\end{tabular}

${ }^{a}$ Two $\times 10^{5} \mathrm{C} 3 \mathrm{H}$ thymus cells were incubated with $3 \times 10^{5} \mathrm{UV}$-irradiated TNP modified syngeneic stimulator cells. The following lymphokine preparations were generated in FCSfree culture medium containing $0.6 \%$ heat-inactivated autologous mouse serum: IL 2, semipurified EL-4 supernatant $(1.450 \mathrm{U} / \mathrm{ml}$ IL 2) $20 \mu \mathrm{l}$; TCF1, Con A-pulsed C3H lymphokine (54 U/ml IL 2) $80 \mu \mathrm{l}$.

${ }^{b}$ The data represent $\%$ specific ${ }^{51} \mathrm{Cr}$-release \pm SD from $5 \times 10^{3}$ prelabelled TNP-L929 target cells or $2 \times 10^{4}$ prelabelled blast cells as targets. 
Table 7. Inhibition of lymphokine-induced cytotoxic responses by cold targets ${ }^{\mathrm{a}}$

\begin{tabular}{|c|c|c|c|c|c|c|c|c|}
\hline \multirow[b]{3}{*}{ Cold targets $^{\mathrm{b}}\left(\times 10^{-4}\right)$} & \multicolumn{8}{|c|}{$\begin{array}{c}\% \text { specific }{ }^{51} \mathrm{Cr} \text {-release }{ }^{\mathrm{c}} \\
\text { Targets }\end{array}$} \\
\hline & \multicolumn{4}{|c|}{$\mathrm{C} 57 \mathrm{BL} / 6$} & \multicolumn{4}{|c|}{$\mathrm{Balb} / \mathrm{c}$} \\
\hline & 0.5 & 2 & 8 & 32 & 0.5 & 2 & 8 & 32 \\
\hline $\mathrm{C} 57 \mathrm{BL} / 6$ & 17.6 & 9.7 & 10.4 & 0.2 & 35.8 & 23.3 & 27.9 & 14.3 \\
\hline $\mathrm{C} 3 \mathrm{H}$ & 19.3 & 16.0 & 11.4 & 8.8 & 33.1 & 18.8 & 17.9 & 10.2 \\
\hline $\mathrm{Balb} / \mathrm{c}$ & 22.4 & 17.0 & 12.8 & 7.9 & 36.0 & 19.9 & 18.5 & 7.1 \\
\hline None & \multicolumn{4}{|c|}{23.2} & \multicolumn{4}{|c|}{35.7} \\
\hline
\end{tabular}

${ }^{a}$ One $\times 10^{5} \mathrm{C} 3 \mathrm{H}$ thymic responder cells were incubated with $3 \times 10^{5}$ glutaraldehyde-fixed C57BL/6 splenic stimulator cells for 5 days in the presence of TCF1 (8U/ml IL 2), $80 \mu \mathrm{l}$ and IL $2(50 \mathrm{U} / \mathrm{ml} \mathrm{IL} 2), 20 \mu \mathrm{l}$.

${ }^{b}$ The cold targets were not labelled with ${ }^{51} \mathrm{Cr}$ but were otherwise prepared according to the same procedure as the labelled cells.

c The data represent $\%$ specific ${ }^{51} \mathrm{Cr}$-release from $2 \times 10^{4}$ labelled target cells.

The data given in Table 6 demonstrate induction of cytotoxic responses with TCF1 plus IL 2 in FCS-free cultures. For these experiments, all lymphokine preparations were also generated under FCS-free conditions. Again, target cells syngeneic to the responder population were lysed when optimal concentrations of TCF1 and IL 2 were present.

\section{Inhibition of cytotoxic responses by the addition of cold targets}

Cold target inhibition studies were done to test whether the cytotoxic effector cells induced by addition of sufficient amounts of IL 2 and TCF1 were specific for a certain target or were nonrestricted. As shown in Table 7, the cytotoxic response induced in $\mathrm{C} 3 \mathrm{H}$ thymic responder cells in the presence of metabolically inactive C $57 \mathrm{BL} / 6$ stimulator cells was directed against both $\mathrm{C} 57 \mathrm{BL} / 6$ and $\mathrm{Balb} / \mathrm{c}$ targets. The lysis of both targets was inhibited with cold targets of either $\mathrm{C} 57 \mathrm{BL} / 6, \mathrm{Balb} / \mathrm{c}$ or $\mathrm{C} 3 \mathrm{H}$ origin. This indicated that the cytotoxic effectors were antigen-unspecific.

\section{Discussion}

The experiments in this report show that cytotoxic effector cells develop from thymocytes in the absence of stimulator cells, provided sufficient helper factors are added to the cultures. This effect was not due to contaminating mitogen in the TCF1 preparations. In earlier reports, we described that the effect of TCF1 was not due to other known lymphokine activities such as IL 1 , IFN- $\gamma$ or CSF $(14,17)$.

Specificity and requirement for the sensitizing antigen were obvious as long as X-irradiated allogeneic stimulator cells and IL 2 were included in 
the thymocyte cultures. When stimulator cells were replaced by TCF1, all offered target cells were lysed. There are several possible explanations for this phenomenon: 1) Antigen contact is not essential for activation of the CTL precursor cells when all necessary helper factors are provided (polyclonal activation). 2) Some specific CTL clones acquire unrestricted cytotoxic potential in the presence of TCF1.3) In vitro cultures contain a whole spectrum of artificial antigens, such as FCS. 4) Some in vivo primed CTL clones are expanded in vitro and crossreact with the targets offered. Cytotoxic responses generated in the absence of FCS (Table 6) indicate, however, that heterologous serum does not explain the antigen-nonspecific cytolytic responses induced by soluble mediators. The relatively weak cytotoxic responses measured in the absence of FCS are to be expected if one considers FCS to exert an enhancing effect (21-23). The cold target inhibition experiment shown in Table 7 suggests that the cytotoxic cells induced by TCF1 are antigen unspecific since their cytotoxic response was inhibited by all target cells. A number of recent reports describe the development of natural killer-like unrestricted cytotoxicity from CTL when lymphokines were provided in large amounts (24-26) or when the cells were cultured for a longer period in the presence of metabolically active stimulator cells $(27,28)$. Preliminary phenotypic characterization of the effector cells in our 5-day lymphokine-induced thymocyte cultures showed that they were sensitive to antibodies against $\mathrm{Lyt}^{-2^{+}}$and complement. About $80 \%$ of the effector cells were positive for Thy-1 and Lyt-2 as shown by fluorescence-activated cell sorting analysis, thus carrying surface markers of CTL. In this respect, these cells resemble the lymphokineactivated, antigen-independent CTLs described by BROOKS et al. (29), and their cytotoxicity resembles the "lymphokine-activated killer cell phenomenon» described by several laboratories $(30,31)$.

The biological effects of TCF1 described here are similar to those effects ascribed to the allogeneic effect factor (AEF) reviewed by ALTMAN and KATZ (32). AEF is reported to augment weak cytotoxic $T$ cell responses and to induce autonomous cytotoxicity, i.e. cytotoxicity in the absence of stimulator cells. It has been shown that AEF preparations induced cytotoxic responses against self and that such responses were not FCSrelated artefacts. Thus, we believe that we are possibly studying the same mechanism of $\mathrm{T}$ cell activation but are using helper mediators from different sources. Also, the availability of semipurified and recombinant IL 2 (Table 3) enables to distinguish between the effect of TCF1 and IL 2 itself.

Recent results from our laboratory indicate that TCF1 is produced by $\mathrm{T}$ helper cells (unpublished results). Thus, it appears that activated $\mathrm{T}$ helper cells as stimulators generate all lymphokines necessary to produce CTL from precursor cells. Recent reports indicate that activated helper $\mathrm{T}$ cells are indeed good stimulator cells for the induction of primary CTL responses $(33,34)$. Specificity of the CTL response in this concept is achieved by the support of only those CTL precursor cells that are in close contact to the 
activated helper $\mathrm{T}$ cell, due to their receptor for the antigenic determinant on the helper cell.

\section{Acknowledgements}

The authors wish to thank BARBARA KATZER for expert technical assistance. We thank Dr. PETER ROBINSON for critical reading of the manuscript. We also acknowledge the assistance of INGRID FRYSON and JUTTA RAMI in the preparation of the manuscript.

Recombinant human IL $2\left(2 \times 10^{5} \mathrm{U} / \mathrm{ml}\right)$ was obtained from CETUS Corporation. The material was $98 \%$ pure and contained $0.02 \mathrm{ng} / \mathrm{ml}$ endotoxin.

\section{References}

1. RöllinghOFF, M., and H. WAGNER. 1975. Secondary cytotoxic allograft response in vitro. I. Antigenic determinants. Eur. J. Immunol. 5: 875.

2. LAFFeRTY, K. J., L. ANDRUS, and S. J. PROwSE. 1980. Role of lymphokine and antigen in the control specific $T$ cell responses. Immunol. Rev. 51: 279.

3. Hurme, M., B. E. BANG, and M. Sihvola. 1980. Generation of H-2-restricted cytotoxic $\mathrm{T}$ cells by ultraviolet light-treated trinitrophenyl-modified syngeneic cells: increased requirement for adherent cells. J. Immunol. 125: 2484.

4. GeRmain, R. N. 1981. Accessory cell stimulation of T cell proliferation requires active antigen processing, Ia-restricted antigen presentation, and a separate nonspecific second signal. J. Immunol. 127: 1964.

5. Larsson, E.-L., M. Gullberg, and A. Coutinho. 1982. Heterogeneity of cells and factors participating in the Concanavalin A-dependent activation of lymphocytes with cytotoxic potential. Immunobiol. 161: 5 .

6. Farrar, J. J., S. B. Mizel, J. Fuller-Farrar, W. L. Farrar, and M. L. Hilfiker. 1980. Macrophage independent activation of helper T cells. I. Production of interleukin 2. J. Immunol. 125: 793.

7. GullberG, M., and E.-L. Larsson. 1982. Selective inhibition of antigen-induced «step one» in cytotoxic T-lymphocytes by anti-Lyt-2 antibodies. Eur. J. Immunol. 12: 1006.

8. LARSSON, E.-L. 1981. Mechanism of T cell activation. II. Antigen- and lectin-dependent acquisition of responsiveness to TCGF is a nonmitogenic, active response of resting $\mathrm{T}$ cells. J. Immunol. 126: 1323.

9. Diamantstein, T., and Z. Chen. 1983. The mechanism of induction of interleukin 2 (IL-2) receptors: An IL-2-receptor-inducing factor, the prerequisite of generation of the receptor. Immunol. 162: 343.

10. Raulet, D. H., and M. J. Bevan. 1982. A differentiation factor required for the expression of cytotoxic T cell function. Nature 296: 754.

11. Wagner, H., C. Hardt, B. T. Rouse, M. Röllinghoff, P. Scheurich, and K. PFIZENMAIER. 1982. Dissection of the proliferative and differentiative signals controlling murine cytotoxic T lymphocyte responses. J. Exp. Med. 155: 1876.

12. Finke, J. H., J. SCOTT, S. Gillis, and M. L. Hilfiker. 1983. Generation of alloreactive cytotoxic $\mathrm{T}$ lymphocytes: Evidence for a differentiation factor distinct from IL-2. J. Immunol. 130: 763.

13. GARMAN, R. D., and D. P. FAN. 1983. Characterization of helper factors distinct from interleukin 2 necessary for the generation of allospecific cytolytic T lymphocytes. J. Immunol. 130: 756.

14. FALK, W., D. N. MÄNNEL, and W. DRÖGE. 1983. Activation of cytotoxic T lymphocytes requires at least two spleen cell-derived helper factors besides interleukin 2. J. Immunol. 130: 2214.

15. Conzelmann, A., P. Corthesy, M. Cianfriglia, A. Silva, and M. Nabholz. 1982. Hybrids between rat lymphoma and mouse $\mathrm{T}$ cells with inducible cytolytic activity. Nature 298: 170. 
16. Conlon, P. J., C. A. Ramthun, C. S. Henney, and S. Gillis. 1982. Cytokinedependent thymocytes from immature thymocytes. J. Immunol. 129: 11.

17. MäNNEL, D. N., W. FALK, and W. DRÖGE. 1983. Induction of cytotoxic T cell function requires sequential action of three different lymphokines. J. Immunol. 130: 2508.

18. PECK, A. B., and F. H. BACH. 1973. A miniaturized mouse mixed leucocyte culture in serum-free and mouse serum supplemented media. J. Immunol. Meth. 3: 147.

19. Hilfiker, M. L., MOORE, R. N., and J. J. FARRAR. 1981. Biologic properties of chromatographically separated murine thymoma-derived interleukin 2 and colony stimulating factor. J. Immunol. 127: 1983.

20. Julius, M. H., E. Simpson, and L. A. HerzenBerg. 1973. A rapid method to the isolation of functional thymus-derived murine lymphocytes. Eur. J. Immunol. 3: 645.

21. FORNI, G., and I. GREEN. 1976. Heterologous sera: a target for in vitro cell mediated cytotoxicity. Immunobiology 156: 121.

22. Golstein, P., M. F. LuCiani, H. Wagner, and M. RÖLlinghoff. 1978. Mouse T cell mediated cytophilic xenogeneic determinants: A caveat for the interpretation of experiments done under «syngeneic» conditions. J. Immunol. 121: 2533.

23. Golstein, P., B. Rubin, F. Denizot, and M. F. Luciani. 1979. Xenoserum-induced cytolytic $\mathrm{T}$ cells: polyclonal specificity with an apparent anti-self component, and cooperative induction. Immunobiology 156: 121.

24. BROOKS, C. G. 1983. Reversible induction of natural killer cell activity in cloned murine cytotoxic T lymphocytes. Nature 305: 155.

25. Merluzzi, V. J., D. M. Savage, R. Mertelsman, and K. Welte. 1984. Generation of nonspecific cytotoxic $T$ cell in vitro by purified human Interleukin 2. Cell. Immunol. 84: 74.

26. Shortman, K., A. Wilson, R. Scollay, and W.-F. Chen. 1983. Development of large granular lymphocytes with anomalous, non-specific cytotoxicity in clones derived from Ly-2+ T cells. Proc. Nat. Acad. Sci. USA 80: 2728.

27. Shortman, K., A. Wilson, and R. Scollay. 1984. Loss of specificity in cytolytic T lymphocyte clones obtained by limit dilution culture of $\mathrm{Ly}^{-2}{ }^{+}$cells. J. Immunol. 132: 584.

28. Simon, M. M., H. U. Weltzien, H. J. Bühring, and K. Eichmann. 1984. Aged murine killer T cell clones acquire specific cytotoxicity for P815 mastocytoma cells. Nature 308: 367.

29. BROOKs, C. G., D. L. URDAL, and C. S. HenNEY. 1983. Lymphokine-driven «Differentiation" of cytotoxic $\mathrm{T}$ cell clones into cells with NK-like specificity: Correlation with display of membrane macromolecules. Immunol. Rev. 72: 43.

30. Altman, A., and D. H. KaTz. 1980. The induction of autoreactive T lymphocytes by allogeneic effect factor (AEF): Relevance to normal pathways of lymphocyte differentiation. Immunol. Rev. 57: 3.

31. Grimm, E., A. MaZunder, H. Z. Zhang, and S. A. Rosenberg. 1982. Lymphokineactivated killer cell phenomenon. Lysis of natural killer-resistant fresh solid tumor cells by interleukin 2-activated autologous human peripheral blood lymphocytes. J. Exp. Med. 155: 1823.

32. Shortman, K., A. Wilson, and R. Scollay. 1984. Loss of specificity in cytolytic T lymphocyte clones obtained by limit dilution culture of Ly $2^{+} \mathrm{T}$ cells. 132: 584 .

33. Dröge, W., D. N. Männel, W. Falk, H. SChmidt, S. Panknin, and W. Dotterer. 1983. The optimal activation of cytotoxic $T$ lymphocytes requires metabolically intact stimulator cells not only for the activation of interleukin 2-producing helper cells. J. Immunol. 131: 520.

34. MOYERS, C., and W. DRÖGE. 1983. Antigenically activated helper $T$ cells are required as stimulator cells for optimal activation of cytotoxic $\mathrm{T}$ lymphocytes under conditions of limiting helper factors. Cell. Immunol. 75: 1.

Dr. D. N. MÄNNEL, Institut für Immunologie und Genetik, Deutsches Krebsforschungszentrum, Im Neuenheimer Feld 280, D-6900 Heidelberg, F.R.G. 